\title{
Fauna of caddisflies (Insecta: Trichoptera) of the Phuket Island, Thailand
}

\section{Фауна ручейников (Insecta: Trichoptera) острова Пхукет, Таицанд}

\author{
H. Malicky ${ }^{1}$, S.I. Melnitsky ${ }^{2}$,V.D. Ivanov ${ }^{2}$ \\ Г. Малиџки ${ }^{1}$, С.И. Мельниџкий ${ }^{2}$ В.А. Иванов ${ }^{2}$
}

\footnotetext{
${ }^{1}$ Sonnengasse 13, 3293 Lunz am See, Austria.

2 St.Petersburg State University, Faculty of Biology, Department of Entomology, Universitetskaya nab. 7/9, St.Petersburg 199034, Russia. E-mail: simelnitsky@gmail.com,v--ivanov@yandex.ru

${ }^{2}$ Санкт-Петербургский государственный университет, биологический факультет, кафедра энтомологии, Университетская наб.7/9, Санкт-Петербург 199034, Россия.
}

KEY WORDS: Trichoptera, caddisflies, fauna, Hydroptilidae, Psychomyiidae, Orthotrichia, Paduniella, taxonomy, Phuket Island.

КЛЮЧЕВЫЕ СЛОВА: Trichoptera, ручейники, фауна, Hydroptilidae, Psychomyiidae, Orthotrichia, Paduniella, систематика, остров Пхукет.

ABSTRACT. The list of the caddisfly species found in Phuket Island has 36 recently recorded species and comprises 47 species. Two new species from the family Hydroptilidae, Orthotrichia tonsai, sp.n. and Psychomyiidae, Paduniella phuketiella, sp.n. are described. Hydroptila rumpun Wells et Huisman, 1992 is new species for Thailand. As a result, 19 species are new for Phuket fauna, 2 new for science, one new for Thailand. Updated list of the Trichoptera species known from Phuket Island with new records is provided.

РЕЗЮМЕ. СПисок видов ручейников, найденных на острове Пхукет, насчитывает 47 видов, из которых 36 видов отмечены авторами. Описаны два новых вида из семейства Hydroptilidae, Orthotrichia tonsai, sp.n. и Psychomyiidae, Paduniella phuketiella, sp.n. Hydroptila rumpun Wells et Huisman, 1992 - новый вид для Таиланда. В peзультате 19 видов являются новыми для фауны Пхукета, один новый для Таиланда. Предоставлен обновлённый список видов ручейников острова Пхукет, с дополнениями.

\section{Introduction}

The fauna of Thailand caddisflies comprises 1020 species from 31 families and 106 genera [Chantaramongkol et al., 2010; Malicky, 2010, 2011, 2012; Laudee, Malicky, 2014]. Leptoceridae, Hydropsychidae, and Hydroptilidae are the most species-rich families. The richest faunas were found in mountain regions at altitudes above $200 \mathrm{~m}$; brooks and small rivers provide the most diverse samples.
Our collecting area is situated on the largest island of Thailand, the Phuket Island, very popular among main touristic destinations of the country. The island has high hills, a part of the Phuket range extending outside the island, surrounded by agricultural plains. This Phuket range is a part of the larger Tenasserim (Tanaosi) Mountain system, the $1,700 \mathrm{~km}$ long mountain chain, extending far northwards and presenting a part of the Indo-Malayan mountain system. The southern section of this extensive chain outside Phuket runs along the Kra Isthmus into the Malay Peninsula. Rivers of Phuket range are not very long because they have their source in these mountains, but since the hills raise directly from the coast there are no notable streams of the island ridge. Few (less than 10) streams of the Phuket Island look more like brooks rather rivers because the hills are low and their basins are small. Usually the western slopes of Phuket range are more densely forested than the eastern for they receive more abundant monsoon rains, although on the island itself this difference is invisible because the distance from the sea is ca. $20 \mathrm{~km}$ for the easternmost point on the island. The forest vegetation forms the South Thailand semi-evergreen rain forests, which are part of the Kayah-Karen/ Tenasserim moist forests ecoregion included in the Global 200 list of ecoregions identified by the World Wildlife Fund (WWF) as priorities for conservation [Olson, Dinerstein, 1998, 2002].

We recognize two distinct Phuket hill sites: the Khao Phra Thaeo region (a protected area on the northeast of the island) and the larger Kamala hill area extending along the western coast mostly at southwestern part of Phuket. None of these hills has elevation exceeding $500 \mathrm{~m}$ above sea level. Phuket has a monsoon climate with dry season running from December through

How to cite this article: Malicky H., Melnitsky S.I., Ivanov V.D. 2019. Fauna of caddisflies (Insecta, Trichoptera) of the Phuket Island, Thailand // Russian Entomol. J. Vol.28. No.4. P.425-432. doi: 10.15298/ rusentj.28.4.11 
March and a wet season that covers the other part of year, with some precipitation even during its dry season.

No special collecting efforts were concentrated on studies of the Phuket caddisflies. As a result, all previous samplings on Phuket have been made only in two localities, Ton Sai Waterfall [Malicky, Chantaramongkol, 1992, 1993; Malicky, 1997; Malicky et al., 2002] and Bang Pae Waterfall [Laudee, Mesuk, 2019]. Waterfalls are located in the Khao Phra Taeo region. Previous findings have shown the presence of 28 species, 9 families, and 15 genera on Phuket Island.

The popularity of the island for tourism stimulates the rapid development of infrastructure, including construction of roads and buildings, deforestation, use of brooks for water supply and extensive agriculture. These changes are influential for the aquatic organisms, so the investigation of freshwater fauna is of high priority. Besides the apparent practical application of faunistic studies for the nature conservation, there are other significant areas dependable on these data. The knowledge of local faunas is necessary for the comparative ecology, biogeography and studies of fauna development, including the island biogeography. Our material, although limited, provides 2 new species for science and one new for the fauna of Thailand and 19 species new for the Phuket fauna.
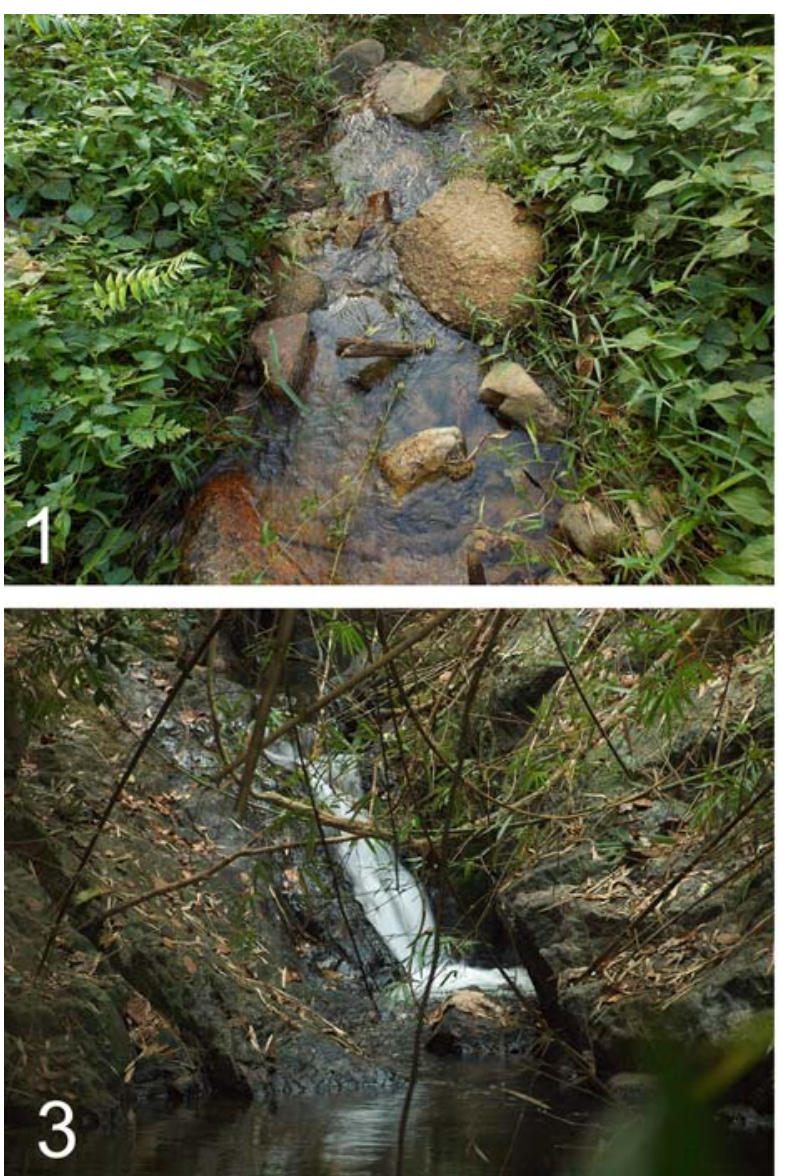

Figs 1-4. Sampling biotopes in Phuket: 1 - stream near Kamala; 2 - Ton Sai, brook in the vicinity of waterfall; 3 - brook downstream of waterfall Bang Pae; 4 - Kathu waterfall at dry season.

Рис. 1-4. Места сбора на острове Пхукет: 1 - ручей рядом с Камалой; 2 - ручей у водопада Тон Сай; 3 - ручей у водопада Банг Пае; 4 - Водопад Кату в сухой сезон.
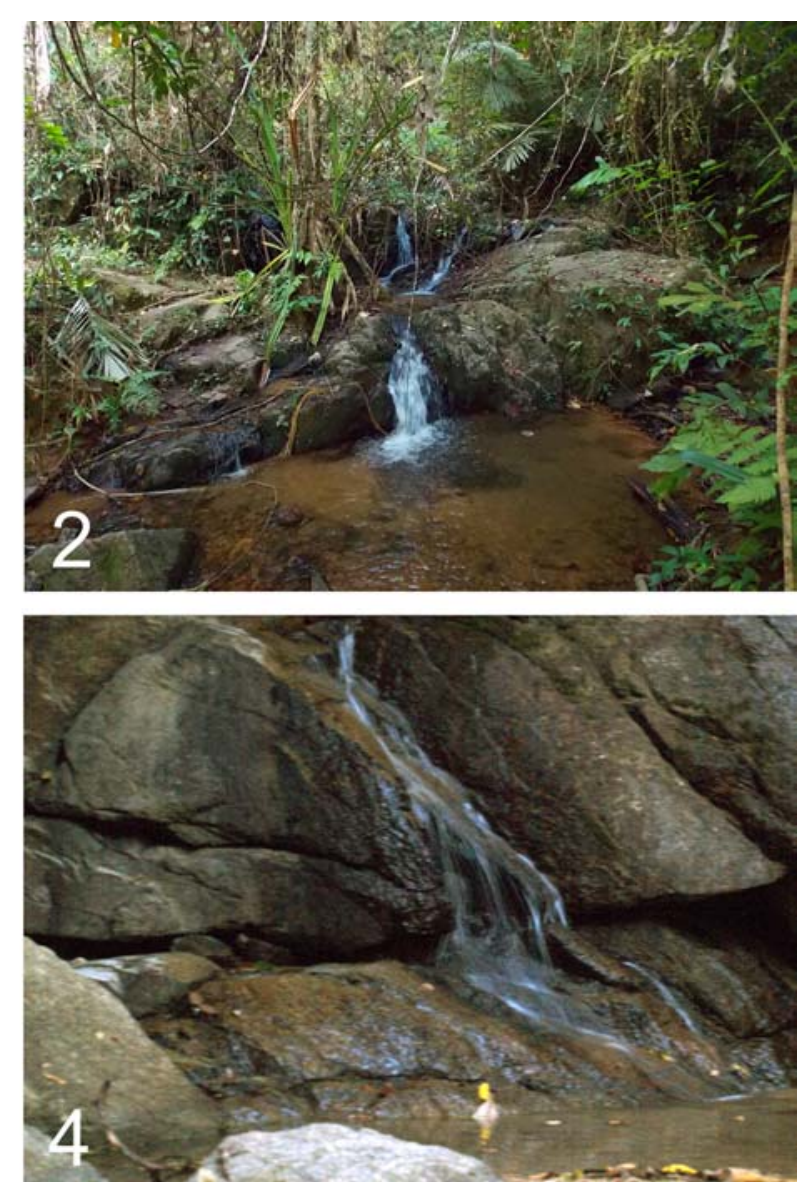

\section{Material and Methods}

The material described and listed here has been collected during the visit of V.D. Ivanov and S.I. Melnitsky to Thailand, Phuket Island, in January 2014. Field collecting included the methods of sampling by small $4 \mathrm{~W}$ UV light pan traps installed close to the water edge, by net sweeping at daytime on the shore vegetation, and hand picking. There were $4-8$ small light traps in one sampling site distributed along a shore at distances 5-50 m operating simultaneously from early dusk during 2 hours. Several smaller traps provide more diverse and abundant material than a single trap even with brighter lamp. Sometimes neighbor traps at distance $5 \mathrm{~m}$ collected significantly different species set. The material is preserved in $70 \%$ or $90 \%$ ethanol and is stored in the collection of the Zoological Institute of Russian Academy of Sciences in St. Petersburg. Some specimens are in the collection of the first author. The types are deposited in the Zoological Institute of the Russian Academy of Sciences, St. Petersburg, Russia.

All sampling sites were on undisturbed parts of brooks under the canopy of trees. The sites (Figs 1-4) were in close proximity of rapids or near waterfalls. All brooks did not show any evidence of significant changes of water 
flow caused by rainfalls at wet season: The riverbeds were not affected by floods and the bank vegetation grew in the proximity of water. Apparently the underground waters play the major part in the brook supplies. Map of the sampling sites is shown on Fig. 5. Sampling localities were as follows:

LOCALITY 1: THAILAND, Phuket, stream near Kamala, $07^{\circ} 56.924^{\prime} \mathrm{N}, 98^{\circ} 18.273^{\prime} \mathrm{E}$, Height $56 \mathrm{~m}$, UV light traps, 28 January 2013, leg. Melnitsky, Ivanov.

LOCALITY 2: THAILAND, Phuket, Ton Sai waterfall, $08^{\circ} 01.694^{\prime} \mathrm{N}, 98^{\circ} 21.944^{\prime} \mathrm{E}$, Height $137 \mathrm{~m}$, UV light traps, 29 January 2013, leg. Melnitsky, Ivanov.

LOCALITY 3: THAILAND, Phuket, Bang Pae waterfall, $08^{\circ} 02.286^{\prime} \mathrm{N}, 98^{\circ} 23.385^{\prime} \mathrm{E}$, Height $89 \mathrm{~m}$, UV light traps, 31 January 2013, leg. Melnitsky, Ivanov.

LOCALITY 4: THAILAND, Phuket, Kathu waterfall, $07^{\circ} 56.063^{\prime} \mathrm{N}, 98^{\circ} 19.388^{\prime} \mathrm{E}$, Height $131 \mathrm{~m}$, UV light traps, 2 February 2013, leg. Melnitsky, Ivanov.

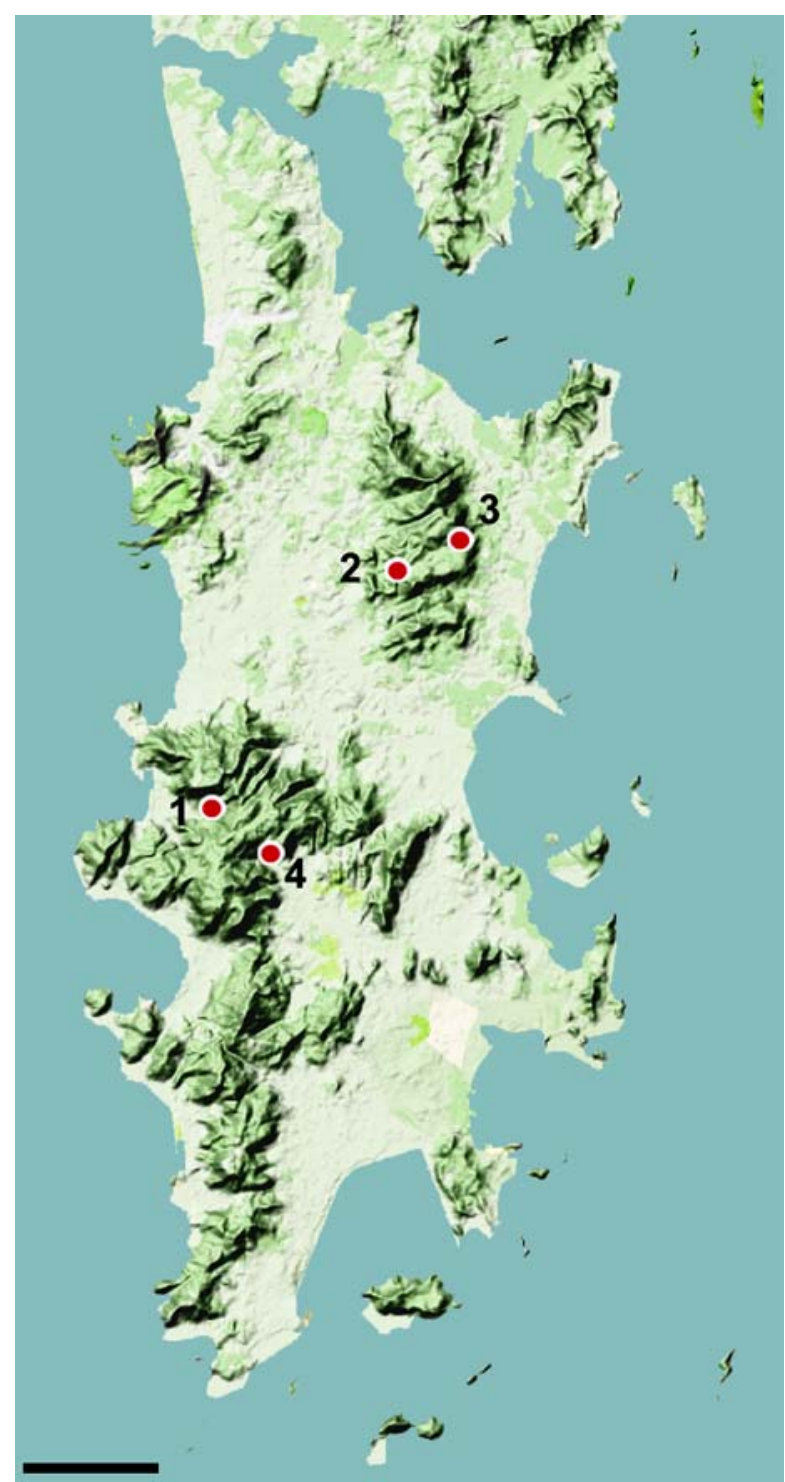

Fig. 5. Map of Phuket with sampling sites (dots). Scale $5 \mathrm{~km}$.

Рис. 5. Карта острова Пхукет с местами сбора (кружки). Масштаб $5 \mathrm{~km}$.

\section{Results}

Hydroptilidae Stephens, 1836

Orthotrichia tonsai

Malicky, Melnitsky et Ivanov, sp.n.

Figs 6-9.

MATERIAL. Holotype, $\sigma^{7}$. Thailand, Phuket, Ton Sai waterfall, $08^{\circ} 01.694^{\prime} \mathrm{N}, 98^{\circ} 21.944^{\prime} \mathrm{E}$, Height $137 \mathrm{~m}$, UV light traps, 29 January 2013, leg. Melnitsky, Ivanov.

DESCRIPTION. Dark brown, ventral parts and genitalia lighter. Fore wing length $3 \mathrm{~mm}$. Male genitalia (Figs 6-9). Like in most of the described Orthotrichia Warren, 1895 species, the genitalia are highly asymmetrical and difficult to describe. The comparison with the drawings is essential. Segment IX relatively short, laterally deeply indented, dorsally nearly quadrangular and rounded, ventrally broadly triangular and rounded. Free inner dark spine is simple and straight. In dorsal view, two thin long projections extend from posterior margin of segment IX at right and left sides, both are bent to the right. Segment X appears in dorsal view nearly rectangular and has at the caudal edge a short left curved tooth. Inferior appendages on ventral view short, compact and of irregular shape with short caudal projections; a pair of pliers-shaped structures protrudes out behind it near the right edge. On lateral view, there are two upward curved ventral claws (inferior appendages), and a small subventral protrusion of the caudal edge of segment IX. Phallus long and thin, with long paramere directed anteriorly and terminally curved backwards as shown in the drawing. Comparison to similar species is not easy because of the strong asymmetry. O. deukalion Malicky et Prommi, 2000 from Northern Thailand has similar inferior appendages and segment $\mathrm{X}$, but the proportions are quite different.

ETYMOLOGY. The species name is derived from the name of locality (waterfall Ton Sai).

DISTRIBUTION. Thailand.

Psychomyiidae Walker, 1852

Paduniella phuketiella

Malicky, Melnitsky et Ivanov, sp.n. Figs 10-14.

MATERIAL. Holotype, $\sigma^{7}$. Thailand, Phuket, stream near Kamala, $07^{\circ} 56.924^{\prime} \mathrm{N}, 98^{\circ} 18.273^{\prime} \mathrm{E}$, Height $56 \mathrm{~m}$, UV light traps, 28 January 2013, leg. Melnitsky, Ivanov.

DESCRIPTION. Yellow-brown, forewing length $2.5 \mathrm{~mm}$. Male genitalia (Figs 10-14). Segment IX in lateral view with thin dorsal part extended posterodorsally. Superior appendages short, rounded in dorsal view, acute in lateral view. Inferior appendages in lateral view long and slender, almost straight, with step-forming incision at the middle of dorsal surface and truncate apex; in ventral view the outer edge is nearly straight and distally curved inwards; dorsal part of inner edge with short, blunt finger-like projection at its middle followed by incision, and the apical parts slightly turned inwards. The phallic apparatus in lateral view with two long, slender branches, of which the dorsal is much longer and pointed; ventral part (phallus) slightly rounded distally, but not thickened. Dorsal to the phallic apparatus, there are two very long slender asymmetric parameres, one of which is straight, the other slightly curled, and turned over the first one. There are many similar species, but the species is easy to recognize by the narrow, not thickened phallus.

ETYMOLOGY. The species name is derived from the name of locality (Island Phuket).

DISTRIBUTION. Thailand. 

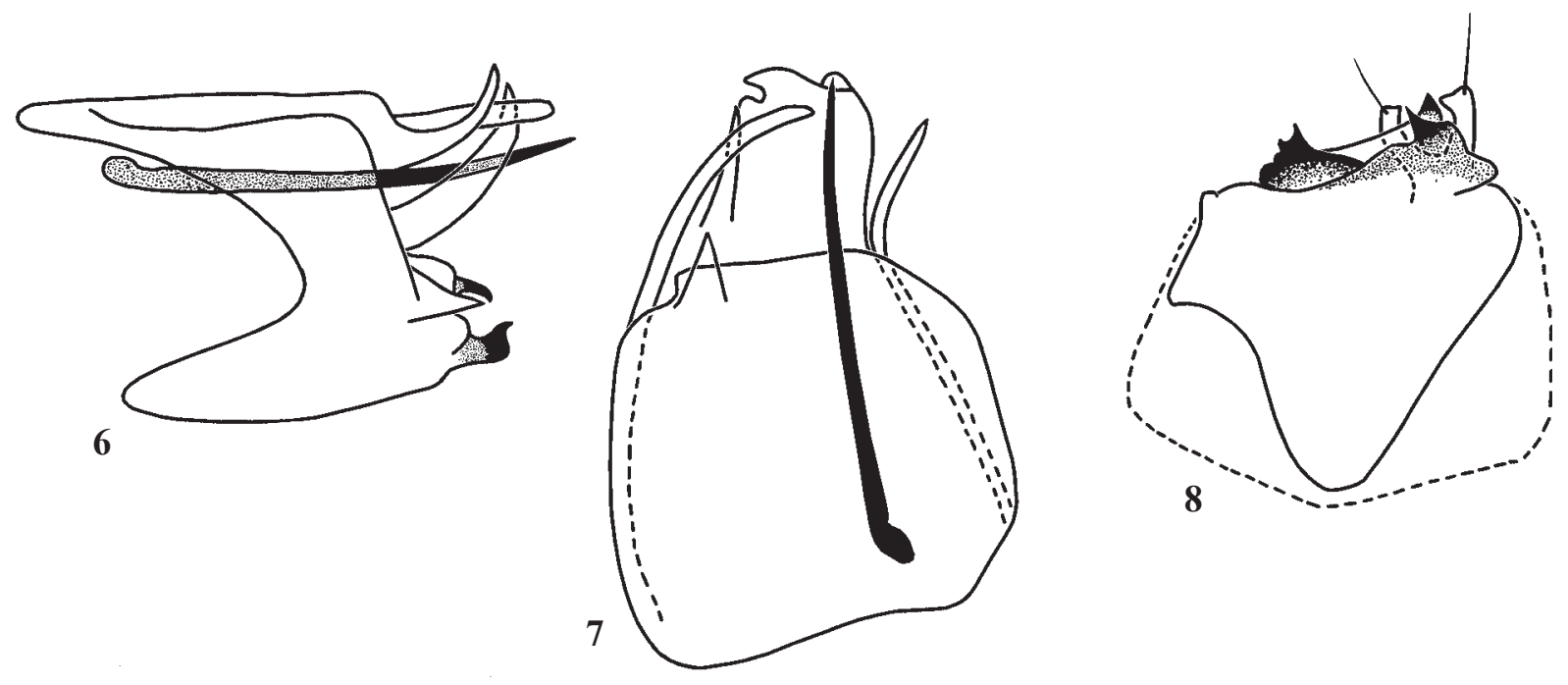

9

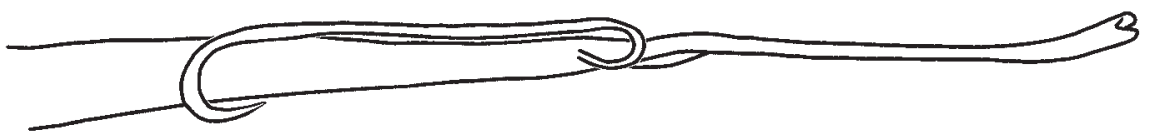

Figs 6-9. Orthotrichia tonsai, Malicky, Melnitsky et Ivanov, sp.n.:, male genitalia: 6 — lateral view; 7 — dorsal view; 8 — ventral view; 9 - aedeagus.

Рис. 6-9. Orthotrichia tonsai, Malicky, Melnitsky et Ivanov, sp.n., гениталии, самец: 6 - латерально; 7 - дорсально; 8 вентрально; 9 - эдеагус.
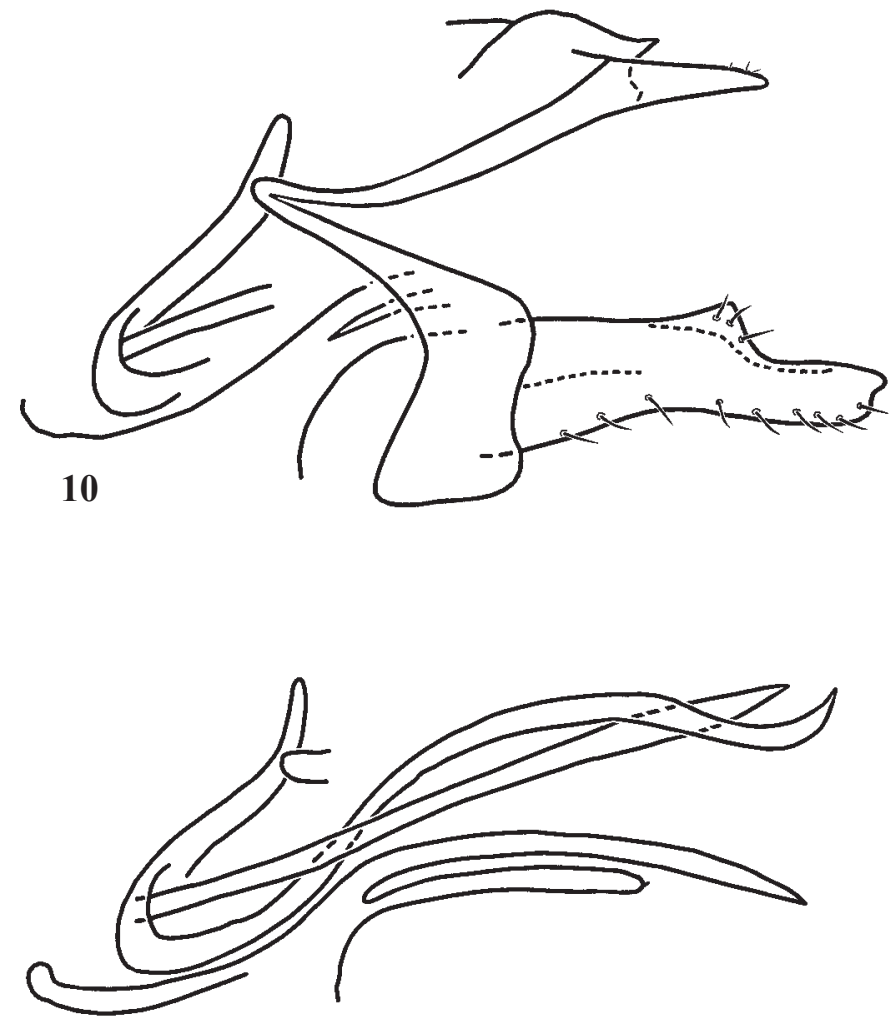

11
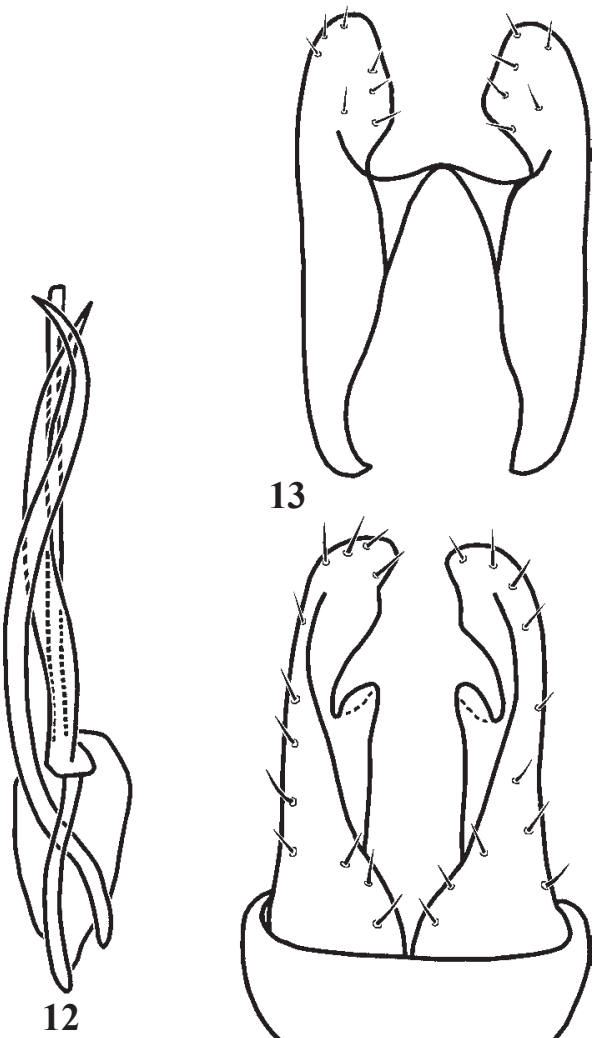

13

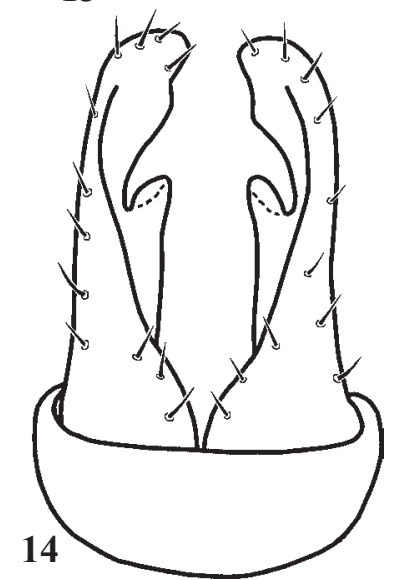

Figs 10-14. Paduniella phuketiella, Malicky, Melnitsky et Ivanov, sp.n., male genitalia: 10 — lateral view, 11 — phallic structures, lateral view, 12 - phallic structures, dorsal view, 13 - dorsal view, 14 - ventral view.

Рис. 10-14. Paduniella phuketiella, Malicky, Melnitsky et Ivanov, sp.n., гениталии, самец: 10 - латерально, 11 - структуры эдеагуса, латерально, 12 - структуры эдеагуса, дорсально, 13 - дорсально, 14 - вентрально. 
Updated list of the Trichoptera species known from Phuket Island

The list summarising the available data, both original and taken from the publications, includes mostly indications of males. This means that the females of many species are not associated with males and hence cannot be identified with certainty. We omit inclusion of these female materials as formal indications like "female sp. 1" to avoid uncertainty concerning the indications of presence of new species. The species previously unknown from Phuket are asterisked $(*)$. The updated faunistic list for Phuket Trichoptera includes 11 families, 27 genera, and 47 species.

RHYACOPHILIDAE Stephens, 1836 Rhyacophila noeibia

Malicky et Chantaramongkol, 1993*

LOCALITIES. L2: $10^{7}$; L3: $10^{7}$.

DISTRIBUTION. Thailand.

HYDROPTILIDAE Stephens, 1836

Hydroptila rumpun Wells et Huisman, 1992

LOCALITIES. L1: $10^{\top}$.

DISTRIBUTION. Indonesia (Sumatra, Lombok), Malaysia (West).

Hydroptila thuna Olah, 1989

LOCALITIES. L1: $10^{7}$.

DISTRIBUTION. Thailand, China, Cambodia, Indonesia (Sumatra), Laos, Nepal, Russia, Vietnam.

\section{Orthotrichia tonsai}

Malicky, Melnitsky et Ivanov, sp.n.

LOCALITIES. L2: 1 ○?.

DISTRIBUTION. Thailand.

Oxyethira bogambara Schmid, 1958

LOCALITIES. L1: $130^{2}$.

DISTRIBUTION. Thailand, Australia, China, India, Indonesia (Sulawesi), Malaysia (West), Nepal, Philippines.

PHILOPOTAMIDAE Stephens, 1829

\section{Chimarra akkaorum}

Chantaramongkol et Malicky, 1989*

DISTRIBUTION. Thailand, Cambodia.

Chimarra alleni Chantaramongkol et Malicky, 1989

LOCALITIES. L1: 10'; L2: $1 \bigcirc^{7}$.

DISTRIBUTION. Thailand, Malaysia (West), Vietnam.

Chimarra atnia Malicky et Chantaramongkol, 1993*

LOCALITIES. L2: $1 \bigcirc^{7}$.

DISTRIBUTION. Thailand, Malaysia (West).

\section{Chimarra khamuorum}

Chantaramongkol et Malicky, 1989*

DISTRIBUTION. Thailand, Vietnam.

Chimarra okuihorum Mey, 1998

LOCALITIES. L1: $7 \bigcirc^{7}$; L 3: $7 \bigcirc^{7}$.

DISTRIBUTION. Thailand, Vietnam.

Chimarra rama Malicky et Chantaramongkol, 1993*

LOCALITIES. L1: $10^{7}$.

DISTRIBUTION. Thailand, Indonesia (Sumatra).
Chimarra reasilvia Malicky et Prommi, 2006*

LOCALITIES. L1: $1 \sigma^{7}$.

DISTRIBUTION. Thailand.

Chimarra ravanna Malicky et Chantaramongkol, 1993*

LOCALITIES. L2: 107

DISTRIBUTION. Thailand, Indonesia (Sumatra), Vietnam.

Chimarra sita Malicky et Chantaramongkol, 1993*

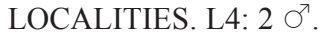

DISTRIBUTION. Thailand, Indonesia (Sumatra).

Chimarra thienemanni Ulmer, 1951

LOCALITIES. L1: $19 \sigma^{7}$; L2: $15 \sigma^{7}$; L3: $11 \sigma^{7}$.

DISTRIBUTION. Thailand, Indonesia (Bali, Java, Sumatra), Malaysia (West).

Gunungiella fimfafiazga

Malicky et Chantaramongkol, 1993*

DISTRIBUTION. Thailand, Malaysia (West).

PSEUDONEURECLIPSIDAE Ulmer, 1951

Pseudoneureclipsis enos

Malicky et Chantaramongkol, 1993*

LOCALITIES. L2: $10^{7}$.

DISTRIBUTION. Thailand.

Pseudoneureclipsis uma

Malicky et Chantaramongkol, 1993*

DISTRIBUTION. Thailand.

DIPSEUDOPSIDAE Ulmer, 1904

Dipseudopsis varians Ulmer, 1929

LOCALITIES. L2: $20^{7}$.

DISTRIBUTION. Thailand, Malaysia (West), Vietnam.

ECNOMIDAE Ulmer, 1903

Ecnomus neri Malicky et Chantaramongkol, 1993*

LOCALITIES. L1: $3{ }^{\top}$.

DISTRIBUTION. Thailand.

PSYCHOMYIIDAE Walker, 1852

Paduniella mibzar

Malicky et Chantaramongkol, 2009*

DISTRIBUTION. Thailand.

Paduniella phuketiella

Malicky, Melnitsky et Ivanov, sp.n.

LOCALITIES. L1: $20^{7}$

DISTRIBUTION. Thailand.

Tinodes ragu Malicky et Chantaramongkol, 1993

LOCALITIES. L1: $10^{7}$

DISTRIBUTION. Thailand, Malaysia (West).

XIPHOCENTRONIDAE Ross, 1949

Abaria iuma Malicky et Chantaramongkol, 1992*

DISTRIBUTION. Thailand.

Abaria guatila Malicky et Chantaramongkol, 1992* DISTRIBUTION. Thailand. 
HYDROPSYCHIDAE Curtis, 1835

Cheumatopsyche dhanikari Malicky, 1979*

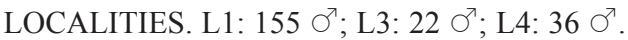

DISTRIBUTION. Thailand, India (Andaman), Myanmar, Vietnam.

Cheumatopsyche globosa (Ulmer, 1910)

LOCALITIES. L1: $1 \sigma^{7}$.

DISTRIBUTION. Thailand, Indonesia (Java, Sumatra), Nepal, Taiwan.

\section{Cheumatopsyche trilari}

Malicky et Chantaramongkol, 1997*

LOCALITIES. L2: $19 \sigma^{7}$; L3: $1 \sigma^{7}$; L4: $2 \sigma^{7}$.

DISTRIBUTION. Thailand, Malaysia (West).

Diplectrona dulitensis Kimmins, 1955*

LOCALITIES. L1: $5 \sigma^{7}$; L2: $10^{7}$; L4: $3 \sigma^{7}$.

DISTRIBUTION. Thailand, Indonesia (Sumatra), Malaysia (West), Myanmar.

Diplectrona gombak Olah, 1993*

LOCALITIES. L1: $1 \sigma^{7}$; L3: $1 \bigcirc^{\top}$.

DISTRIBUTION. Thailand, Malaysia (West).

Hydromanicus abiud

Malicky et Chantaramongkol, 1993*

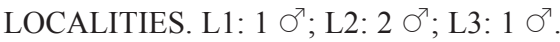

DISTRIBUTION. Thailand.

\section{Hydromanicus klanklini}

(Malicky et Chantaramongkol, 1993) * Vietnam.

DISTRIBUTION. Thailand, Malaysia (West), Myanmar,

Hydromanicus serubabel

Malicky et Chantaramongkol, 1993*

LOCALITIES. L1: 15 O $^{7}$; L2: 3 O $^{7}, 1$ ㅇ.

DISTRIBUTION. Thailand.

Hydropsyche camillus

Malicky et Chantaramongkol, 2000

LOCALITIES. L1: $60^{7}$.

DISTRIBUTION. Thailand, Vietnam.

Macrostemum fenestratum (Albarda, 1881)*

LOCALITIES. L1: $30^{\top}, 8$ + ; L2: $10^{\top}, 1$ +; L3: 4 + ; L4: $10^{\top}$. DISTRIBUTION. Thailand, Indonesia (Sumatra), Laos, Malaysia (West), Vietnam.

Macrostemum floridum (Navas, 1929)*

DISTRIBUTION. Thailand, China, Cambodia, India,Vietnam.

\section{HELICOPSYCHIDAE Ulmer, 1906}

\section{Helicopsyche boniata}

Malicky et Chantaramongkol, 1992*

LOCALITIES. L1: $12 \sigma^{7}$; L2: $1 \sigma^{7}$; L3: $1 \sigma^{7}$; L4: $1 \sigma^{7}$. DISTRIBUTION. Thailand, Laos, Vietnam.

LEPTOCERIDAE Leach, 1815

Adicella evadne Schmid, 1994*

DISTRIBUTION. Thailand, China, India, Indonesia (Bali, Lombok, Sumatra).
Adicella koronis Malicky et Thani, 2002*

DISTRIBUTION. Thailand.

Leptocerus dirghachuka Gordon et Schmid, 1987

LOCALITIES. L1: $10^{7}, 1$ क; L4: $10^{7}$.

DISTRIBUTION. Thailand.

Oecetis asmada Malicky, 1979

LOCALITIES. L4: 10 ?.

DISTRIBUTION. Thailand, India (Andaman), Indonesia (Sumatra), Vietnam.

Oecetis hemerobioides (McLachlan, 1866)

LOCALITIES. L1: $1 \sigma^{7}$.

DISTRIBUTION. Thailand, Australasian Region, Oriental Region.

\section{Oecetis misenos}

Malicky et Chantaramongkol, 2005

LOCALITIES. L4: 1 \%".

DISTRIBUTION. Thailand.

Oecetis tripunctata (Fabricius, 1793)

LOCALITIES. L2: $2 \sigma^{7}$; L3: 1 \%.

DISTRIBUTION. Thailand, Oriental Region, Palearctic Region.

Setodes sarapis Malicky et Chantaramongkol, 2006

LOCALITIES. L1: 4 or.

DISTRIBUTION. Thailand, Indonesia (Sumatra).

Setodes thoneti Malicky et Chantaramongkol, 2006

LOCALITIES. L1: 3 or.

DISTRIBUTION. Thailand, Cambodia, Laos.

Triaenodes dusrus Schmid, 1965*

LOCALITIES. L1: $6 \sigma^{7}, 3$ ㅇ L2: $1 \sigma^{7}$; L3: $3 \sigma^{7}$.

DISTRIBUTION. Thailand, Indonesia (Sumatra), Malaysia (West), Vietnam.

\section{Discussion}

The fauna of caddisflies on numerous islands of Southeast Asia has been studied fragmentary and insufficiently [Malicky et al., 2014]. Some of previously described species found in our samples appeared to be endemic for the Phuket Island: Rhyacophila noeibia, Pseudoneureclipsis enos, and Abaria iuma. With two new species described in this paper, Orthotrichia tonsai sp.n., and Paduniella phuketiella sp.n., the number of the Trichoptera endemics on this island reaches five. This number looks small comparing to remote oceanic islands similar to Phuket in size, relief, and biota, e.g., the Mae Island of Seychelles [Malicky, 1993, 1995]. Contrary to Mae, the Phuket Island is close to the mainland separated by a strait some $500 \mathrm{~m}$ wide in its narrowest place. Phuket Island has an area of 543 square kilometers. The Malaysian Langkawi Island is comparable in area to the Phuket Island and is located southeast $215 \mathrm{~km}$ from it. The fauna of the caddisfly species found in the Langkawi Island has 68 species from 31 genus and 15 families [Melnitsky et al., 2019]. There are 22 species found on both islands: Hydroptila rumpun, Oxyethira bogambara, Chimarra 
alleni, Ch. atnia, Ch. okuihorum, Ch. ravanna, Ch. thienemanni, Gunungiella fimfafiazga, Dipseudopsis varians, Ecnomus neri, Tinodes ragu, Cheumatopsyche globosa, Ch. trilari, Diplectrona dulitensis, D. gombak, Hydromanicus klanklini, Macrostemum fenestratum, Oecetis hemerobioides, O. misenos, Setodes sarapis, and $S$. thoneti.

Comparison to the data by P. Laudee and T. Prommi on biodiversity of Trichoptera in adjacent province Surat Thani, approximately $100 \mathrm{~km}$ to the east, shows very low faunistic similarity of these study areas [Laudee, Prommi, 2011]. These discrepancies might be resulted from different approaches: The Surat Thani study is based on the year-long sampling in 15 places with three month intervals whereas our research was limited by a few days in a peak of dry season. No surprise hence that the species list of Surat Thani is much longer (105 species) than that of Phuket with 47 species. The composition of the two faunas is strikingly different. There are only ten species shared by two lists: Hydroptila thuna, Dipseudopsis varians, Diplectrona dulitensis, Hydropsyche camillus, Macrostemum fenestratum, $M$. floridum, Leptocerus dirghachuka, Oecetis asmada, Oe. tripunctata, Setodes thoneti. These are widespread species, some of them (Oe. tripunctata) are known from Palearctic, others are known from various provinces of Thailand and usually from the neighboring countries. Two families found in Phuket samples: Xiphocentronidae and Helicopsychidae, were not collected in Surat Thani; contrary, Stenopsychidae, Brachycentridae, Goeridae, Lepidostomatidae, Odontoceridae, and Calamoceratidae were not found in Phuket. Current difference in two faunas apparently reflects the poor knowledge of both faunas and stresses the importance of further sampling and faunistic studies in the region.

Inadequate knowledge makes the statistical comparison unreliable in the moment and we did not calculate the differences. Another source of uncertainty is the limitations caused by poor knowledge of females and larvae; the species for which the females are unknown are listed only by males. We did not collect larvae because of impossibility of their determinations to species level. The limited data on Phuket fauna of Trichoptera requires more data to compare them to other regions with certainty; the material from adjacent Phang Nga and Krabi Provinces is much desirable to understand the composition and development of Phuket fauna.

The differences within the Phuket Province faunas are remarkable: 25 species are founded in the Ton Sai and Bang Pae streams (localities 2, 3) and 31 are known for Kamala and Kathu (localities 1, 4) whereas only ten species are shared by these two hill regions. These differences were probably caused by isolation of the hill faunas by sea straits in the past when the sea level was much higher than now and by agricultural landscape with polluted waters nowadays.

Local distribution of the Trichoptera species in South East Asia stresses the vulnerability of fauna to possible harmful influences. Limited distribution and small population size make local extinctions irreversible because remote populations, if exist, are beyond the range of dispersal. The available data suggest the peculiarity of the Phuket fauna and support the inclusion of the KayahKaren/Tenasserim moist forests ecoregion into the Global 200 list of conservation areas [Olson, Dinerstein, 1998, 2002]. The moist forests on slopes of Phuket hills are accessible for local people and tourists, and might suffer of logging, water supply construction, hotels development and other human activities. Tourism itself in the extremely popular tourist destination is less important factor of vulnerability than the indirect impact from infrastructure growth. Risks of extinction at present seem to be relatively low because of steep hill slopes and limited accessibility of upper parts of streams. Nonetheless the increasing human impacts to local biocenoses might grow with tourist industry development and cause changes of local streams. The continuing monitoring of the fauna hence is important for control of influences to fauna and might prevent the faunal impoverishment.

Acknowledgements. The reported study was funded by RFBR, project number 18-04-00312. Saint Petersburg State University grants 1.42.1017.2016, 1.42.1011.2016 1.42.721.2017 (Id: 33161520), 1.42.722.2017 (Id: 33161571), CONF2018 1 (Id: 27870985), COLLAB2019_1 (ID: $37746533)$.

\section{References}

Chantaramongkol P., Thapanya D., Bunlue P. 2010. The Aquatic Insect Research Unit(AIRU) of Chiang Mai University, Thailand, with an updated list of the Trichoptera species of Thailand // Denisia. Vol.29. P.55-79.

Laudee P., Mesuk K. 2019. Biodiversity of Trichoptera from waterfalls on island in the Thai Gulf and The Andaman Sea, Thailand // Zoosymposia. Vol.14. P.108-112.

Laudee P., Malicky H. 2014. Trichoptera fauna from Nakhon Si Thammarat Range (southern Thailand), with the description of a new species of Rhyacophila Pictet, 1834 (Trichoptera: Rhyacophilidae) // Aquatic Insects. No.36. P.161-169.

Laudee P., Prommi T. 2000. Biodiversity and distribution of Trichoptera species along the Tapee River, Surat Thani Province, southern Thailand // Zoosymposia. Vol.5. P.279-287.

Malicky H. 1993. Three new caddisflies from Mahe Island, Seychelles // Braueria. No.20. P.19-21.

Malicky H. 1995. The caddisflies (Insecta; Trichoptera) of Seychelles: taxonomy, zoogeography, biology and conservation // Phelsuma. No.3. P.15-22.

Malicky H. 1997. Ein Beitrag zur Kenntnis asiatischer Arten der Gattungen Cheumatopsyche Wallengren 1891 und Potamyia Banks 1900 (Trichoptera, Hydropsychidae) (Zugleich 22. Arbeit über thailändische Köcherfliegen) // Linzer Biologische Beiträge. Bd.29. Hf.2. S.1015-1055.

Malicky H. 2010. Atlas of Southeast Asian Trichoptera. Biology Department, Chiangmai University. 346 pp.

Malicky H. 2011. Neue Trichopteren aus Europa und Asien // Braueria. No.38. P.23-43.

Malicky H. 2012. Neue asiatische Köcherfliegen aus neuen Ausbeuten (Insecta, Trichoptera) // Linzer biologische Beiträge. Bd.44. Hf.2. S.1263-1310.

Malicky H., Chantaramongkol P.1992. Neue Köcherfliegen (Trichoptera) aus Thailand und angrenzenden Ländern (Arbeiten über thailändische Köcherfliegen Nr. 11) // Braueria. No.19. P.13-23

Malicky H., Chantaramongkol P. 1993. Neue Trichopteren aus Thailand. Teil 1: Rhyacophilidae, Hydrobiosidae, Philopotami- 
dae, Polycentropodidae, Ecnomidae, Psychomyidae, Arctopsychidae, Hydropsychidae (Arbeiten über thailändische Köcherfliegen Nr. 12) // Linzer Biologische Beiträge. Bd.25. H.1. S.433-487.

Malicky H., Chantaramongkol P., Saengpradab N., Chaibu P., Thani I., Changthong N., Cheunbarn S., Laudee P., Prommi T., Sompong S. 2002. Neue asiatische Leptoceridae (Trichoptera) (Zugleich Arbeit Nr. 33 über thailändische Köcherfliegen) // Braueria. No.29. P.15-30.

Malicky H., Ivanov V.D., Melnitsky S.I. 2014. Caddisflies (Trichoptera) from Lombok, Bali and Java (Indonesia), with a discussion of the Wallace line // Deutsche Entomologische Zeitschrift. Vol.61. No.1. P.3-14.

Melnitsky S.I., Ivanov V.D. Malicky H. 2019. Fauna of caddisflies (Trichoptera) of Langkawi Island, Malaysia // Entomological Review. Vol.99. No.4. P.534-543.

Olson D.M., Dinerstein E. 1998. The Global 200: A representation approach to conserving the Earth's most biologically valuable ecoregions // Conservation Biology. Vol.12. P.502-515.

Olson D.M., Dinerstein E. 2002. The Global 200: Priority ecoregions for global conservation. Annals of the Missouri Botanical Garden Vol.89. No.2. P.199-224. 